OPEN ACCESS

Edited by:

Lingqian Wu,

Central South University, China

Reviewed by:

Corrado Romano, Oasi Research Institute (IRCCS), Italy Joanna Nowacka-Woszuk,

Poznan University of Life

Sciences, Poland

*Correspondence:

Yiming Lin

linyiming0819@sina.com

Yingjun Xie

xieyjun@mail2.sysu.edu.cn

tThese authors have contributed equally to this work and share first authorship

Specialty section This article was submitted to Genetics of Common and Rare

Diseases,

a section of the journal

Frontiers in Pediatrics

Received: 19 March 2021 Accepted: 26 April 2021

Published: 11 June 2021

Citation:

Zhuang J, Chen C, Li J, Jiang Y, Wang J, Wang $Y$, Zeng S, Lin $Y$ and Xie Y (2021) The 46, XX Ovotesticular

Disorder of Sex Development With Xq27.1q27.2 Duplication Involving the SOX3 Gene: A Rare Case Report and

Literature Review.

Front. Pediatr. 9:682846.

doi: 10.3389/fped.2021.682846

\section{The 46, XX Ovotesticular Disorder of Sex Development With Xq27.1q27.2 Duplication Involving the SOX3 Gene: A Rare Case Report and Literature Review}

\author{
Jianlong Zhuang ${ }^{1+}$, Chunnuan Chen ${ }^{2 t}$, Jia Li ${ }^{3}$, Yuying Jiang ${ }^{1}$, Junyu Wang ${ }^{1}$, \\ Yuanbai Wang ${ }^{1}$, Shuhong Zeng ${ }^{1}$, Yiming Lin ${ }^{4 *}$ and Yingjun Xie ${ }^{5,6 *}$ \\ 1 Prenatal Diagnosis Center, Quanzhou Women's and Children's Hospital, Quanzhou, China, ${ }^{2}$ Department of Neurology, The \\ Second Affiliated Hospital of Fujian Medical University, Quanzhou, China, ${ }^{3}$ Beijing Genomics Institute-Genomics, Beijing \\ Genomics Institute-Shenzhen, Shenzhen, China, ${ }^{4}$ Neonatal Disease Screening Center of Quanzhou, Quanzhou Women's \\ and Children's Hospital, Quanzhou, China, ${ }^{5}$ Department of Obstetrics and Gynecology, Key Laboratory for Major Obstetric \\ Diseases of Guangdong Province, The Third Affiliated Hospital of Guangzhou Medical University, Guangzhou, China, ${ }^{6}$ Key \\ Laboratory of Reproduction and Genetics of Guangdong Higher Education Institutes, The Third Affiliated Hospital of \\ Guangzhou Medical University, Guangzhou, China
}

Background: Very few reports are available on human XX ovotesticular disorder of sex development involving SOX3 gene duplication. Here we aim to present a rare case of SOX3 gene duplication in a person from the Chinese population who exhibits $X X$ ovotesticular disorder of sex development.

Case Presentation: A 7-year-old Chinese individual from Fujian province in Southeast China was recruited. The patient presented 46, XX karyotype, absence of sex-determining region $\mathrm{Y}$, and was diagnosed with $\mathrm{XX}$ ovotesticular disorder of sex development. Furthermore, SNP array analysis demonstrated that the patient had a 2.2-Mb duplication in the Xq27.1q27.2 region (arr[hg19]Xq27.1q27.2:139,499,778-141,777,782) involving the SOX3 gene. Additionally, no SOX3 duplication was observed in the parents or the sibling, who displayed none of the clinical features.

Conclusion: We identified the first case of SOX3 duplication in a Chinese individual who exhibits ovotesticular disorder of sex development. Our study strengthens the link between the SOX3 duplication and XX ovotesticular disorder of sex development and indicates that SOX3 is the evolutionary antecedent of sex-determining region $\mathrm{Y}$.

\footnotetext{
Keywords: disorder of sex development, ovotestis, Xq27.1q27.2 duplication, SOX3 gene, chromosomal microarray analysis
}

\section{INTRODUCTION}

Sex-determining region $\mathrm{Y}(S R Y)$ is the key gene in 46, $\mathrm{XY}$ normal males. $S R Y$ initiates a complex genetic cascade, promoting the differentiation of the testis. However, the coexistence of ovarian and testicular tissues is present in some 46, XX individuals, which refers to as ovotesticular disorder of sex development (OT-DSD) $(1,2)$. Studies have shown that 
the occurrence of $46, \mathrm{XX}$ OT-DSD is related to the dislocation recombination on the $\mathrm{X}$ and $\mathrm{Y}$ chromosomes during the meiosis of the paternal chromosome, which transfers the SRY gene from the Y chromosome to X (3), but only few patients with 46, XX OT-DSD have a detectable SRY gene; most of the subjects show an absence of the $S R Y$ gene $(4,5)$. However, the SRY gene is present in most of $(\sim 80 \%) 46$, XX testicular DSD cases (6). Currently, it is believed that sex determination and differentiation are processes of orderly and coordinated expression of autosomal and sex chromosomes, but with the SRY gene, abnormalities in any process can lead to sex abnormalities.

As we know, SRY up-regulates the expression of SRYBox transcription factor 9 (SOX9) in bipotential gonads, leading to the differentiation of testicular cells and eventually testicular differentiation (7). Moreover, a study has shown that ectopic SOX9 expression induces the formation of mouse testis in XX gonads (8). Recently, several cases have been reported to carry SOX9 duplications (9-12), which have been proposed to be responsible for SOX9 expression during gonad development. SRY-Box transcription factor 3 (SOX3), located on the chromosome $\mathrm{X}$ (Xq27.1), is a member of the SRYBox transcription factor family (13). Duplications involving the SOX3 gene have been reported to be associated with developmental delay, intellectual disability, growth hormone deficiency, infundibular hypoplasia and hypopituitarism, etc. $(14,15)$.

Recently, XX sex reversal has been reported in transgenic mice with ectopic SOX3 expression and observed in 46, XX DSD patients with duplications of SOX3 or genomic rearrangements within the $S O X 3$ regulatory region (16). Few reports are available on 46, XX SRY-negative males with SOX3 duplications, though a recent study conducted by Tasic et al. revealed a 46, XX male who presented congenital anomalies of kidneys and the urinary tract and had a duplication on chromosome Xq27 involving the SOX3 gene, indicating links between SOX3 gene dosage and kidney malformations and sex determination (17). Moreover, a study has shown a 46, XX SRY-negative individual with duplication of the SOX3 gene exhibiting XX OT-DSD (18). In the present study, we describe a 7-year-old OT-DSD case with Xq27.1q27.2 duplication involving the SOX3 gene, which was first identified in Chinese individuals and additionally strengthened the pathogenic role of SOX3 duplication in XX OT-DSD.

\section{CASE PRESENTATION}

The patient comes from Quanzhou City, Fujian province, in Southeast China. The child was delivered vaginally with a birth weight of $3.7 \mathrm{~kg}$. There was no family history of DSD, and the parents denied any consanguinity. A physical examination showed the child presented ambiguous sex, coronal hypospadias, a penis or enlarged clitoris, and the presence of a scrotum but non-palpable gonads. Subsequent ultrasonography indicated that the patient might have the coexistence of testicular and ovarian tissues on the left side and testicular tissue on the right side. After clinical consultation, the family decided to raise the child as a male, and ovariectomy was performed at 10 months after birth, to remove the ovarian section from the left ovotesticular area. The subsequent histology analysis confirmed the presence of unilateral ovotestes tissues in the left side of the patient.

At age 7 , the child's height $(130 \mathrm{~cm})$ and weight $(23 \mathrm{~kg})$ were within the normal ranges. Hormonal laboratory tests showed low luteinizing hormone $(<0.20 \mathrm{mIU} / \mathrm{ml})$, follicle-stimulating hormone $(1.21 \mathrm{mIU} / \mathrm{ml})$ and testosterone $(<0.10 \mathrm{ng} / \mathrm{ml})$. Serum progesterone and prolactin were normal. Currently, human menopausal gonadotropin (menotropins for injection, AnHui BBCA Pharmaceutical Co., Ltd.) is injected for treatment with $150 \mathrm{U}$ a day. Regular follow-up showed normal penile and testicular development, with normal morning erection.

Chromosome G-banding analysis revealed a normal karyotype (46, XX) in the patient. The parental karyotypes were normal as well. Chromosomal microarray analysis demonstrated that the patient had a 2.2-Mb duplication in the Xq27.1q27.2 region (arr[hg19]Xq27.1q27.2:139,499,778-141,777,782) of the $\mathrm{X}$ chromosome (Figure 1). The duplication contains 12 Online Mendelian Inheritance in Man (OMIM) genes: CDR1, LDOC1, MAGEC1, MAGEC2, MAGEC3, SOX3, SPANXA1, SPANXA2, SPANXB1, SPANXB2, SPANXC, and SPANXD. SNP array analysis was also performed on parental and sibling blood samples. Chromosomal microarray results showed that none of the Y chromosome was observed, and further study indicated

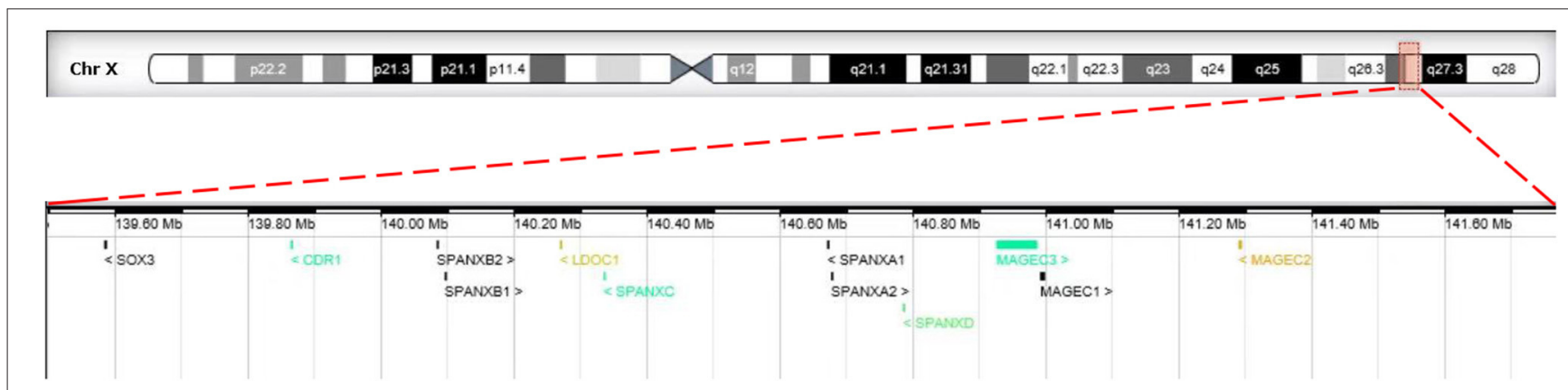

FIGURE 1 | The breakpoint of Xq27.1q27.2 duplication in our study. The upper panel shows the schematic representation of chromosome X. The red rectangle displays the genomic location of Xq27.1q27.2 on the chromosome X. The lower panel presents a magnified view of the Xq27.1q27.2 duplication (arr[hg19] chrX: $139,499,778-141,777,782)$ involving the SOX3 gene. 
TABLE 1 | Literature review of the involvement of SOX3 duplications in disorders of sex development.

\begin{tabular}{|c|c|c|c|c|c|c|c|}
\hline & $\begin{array}{l}\text { Wood et al., } \\
\text { Family A Patient } \\
1\end{array}$ & $\begin{array}{l}\text { Wood et al., } \\
\text { Family A } \\
\text { Patient } 2\end{array}$ & $\begin{array}{l}\text { Sutton et al., } \\
\text { Patient A }\end{array}$ & $\begin{array}{l}\text { Sutton et al., } \\
\text { Patient C }\end{array}$ & $\begin{array}{l}\text { Moalem et al., } \\
\text { Patient } 1\end{array}$ & $\begin{array}{l}\text { Grinsponet al., } \\
\text { Patient }\end{array}$ & Our case \\
\hline $\begin{array}{l}\text { Disorders of sex } \\
\text { development }\end{array}$ & XX male reversal. & XX male reversal. & XX male reversal. & XX male reversal. & $X X$ male reversal. & OT-DSD & OT-DSD \\
\hline Age & 7 years & 2.5 years & 30 years & 1.5 years & 1 year & 2.5 years & 7 years \\
\hline $\begin{array}{l}\text { Growth and } \\
\text { developmental } \\
\text { issues }\end{array}$ & $\begin{array}{l}\text { GH deficiency; } \\
\text { Normal serum } \\
\text { prolactin and } \\
\text { cortisol. } \\
\text { Psychomotor } \\
\text { development. }\end{array}$ & $\begin{array}{l}\text { History of neonatal } \\
\text { hypoglycemia; } \\
\text { severe cortisol, } \\
\text { TSH, GH, and } \\
\text { gonadotrophin } \\
\text { deficiency. He has } \\
\text { normal } \\
\text { psychomotor } \\
\text { development but } \\
\text { has been noted to } \\
\text { be hyperactive. }\end{array}$ & Normal & $\begin{array}{l}\text { Developmental } \\
\text { and growth delay; } \\
\text { microcephaly. }\end{array}$ & Normal & Normal & Normal \\
\hline Genitals and testis & $\begin{array}{l}\text { Details not } \\
\text { reported. }\end{array}$ & $\begin{array}{l}\text { Hypoplastic } \\
\text { genitalia, with both } \\
\text { testes palpable } \\
\text { high in the inguinal } \\
\text { canal and a } \\
\text { micropenis. }\end{array}$ & $\begin{array}{l}\text { Details not } \\
\text { reported. }\end{array}$ & $\begin{array}{l}\text { Right testicles } \\
\text { appear smaller } \\
\text { than left; } \\
\text { Hypoplastic } \\
\text { scrotum; testes } \\
\text { are retractile and } \\
\text { can be brought } \\
\text { down. }\end{array}$ & $\begin{array}{l}\text { Penoscrotal } \\
\text { hypospadias with } \\
\text { a bifid scrotum; } \\
\text { phallus was } \\
\text { otherwise } \\
\text { unremarkable with } \\
\text { erectile tissue } \\
\text { palpable; on } \\
\text { ultrasound } \\
\text { epididymis } \\
\text { appearing grossly } \\
\text { normal. }\end{array}$ & $\begin{array}{l}\text { The testicular } \\
\text { tissue and ovarian } \\
\text { tissue all exist. }\end{array}$ & $\begin{array}{l}\text { The ovotesticular } \\
\text { tissue on the left } \\
\text { side and the } \\
\text { testicular tissue on } \\
\text { the right side. }\end{array}$ \\
\hline Vulva & Male & Male & Male & Male & $\begin{array}{l}\text { Bilateral } \\
\text { cryptorchidism. }\end{array}$ & $\begin{array}{l}\text { Hypospadias and } \\
\text { bilateral } \\
\text { cryptorchidism. }\end{array}$ & $\begin{array}{l}\text { Hypospadias and } \\
\text { bilateral } \\
\text { cryptorchidism. }\end{array}$ \\
\hline SRY & Unknown & Unknown & Negative & Negative & Negative & Negative & Negative \\
\hline Genotypes & $\begin{array}{l}\text { Tandem } \\
\text { duplication } \\
685.6 \mathrm{~kb} \text { in length } \\
\text { on the X } \\
\text { chromosome that } \\
\text { spanned the SOX3 } \\
\text { gene. }\end{array}$ & $\begin{array}{l}\text { Tandem } \\
\text { duplication } \\
685.6 \mathrm{~kb} \text { in length } \\
\text { on the } \\
\text { X-chromosome } \\
\text { which spanned } \\
\text { the SOX3 gene }\end{array}$ & $\begin{array}{l}\text { Two } \\
\text { microduplications } \\
\text { were observed, } \\
\text { the first of which } \\
\text { spanned the entire } \\
\text { SOX3 gene }\end{array}$ & $\begin{array}{l}6 \mathrm{Mb} \text { duplication } \\
\text { that encompasses } \\
\text { SOX3 and at least } \\
18 \text { additional } \\
\text { distally located } \\
\text { genes. }\end{array}$ & $\begin{array}{l}\text { Three } \\
\text { microduplications } \\
\text { were observed, } \\
\text { the first of which } \\
\text { contains the SOX3 } \\
\text { gene. }\end{array}$ & $\begin{array}{l}502 \mathrm{~kb} \text { duplication } \\
\text { that encompasses } \\
\text { SOX3 gene and its } \\
\text { regulatory } \\
\text { sequences. }\end{array}$ & $\begin{array}{l}2.2 \mathrm{Mb} \text { duplication } \\
\text { that encompasses } \\
\text { SOX3 gene. }\end{array}$ \\
\hline Inheritance & Maternally derived. & Maternally derived & Unknown & Unknown & De novo & De novo & De novo \\
\hline
\end{tabular}

that no $S R Y$ gene was observed in the patient by polymerase chain reaction. Furthermore, no SOX3 duplication was observed in the parents or the sibling with normal phenotype.

\section{DISCUSSION AND CONCLUSION}

OT-DSD is the disease defined as presence of both male and female gonads. The $S R Y$ gene is present in few cases of $46, \mathrm{XX}$ OT-DSD patients, which can explain testicular development (18). However, the SRY gene is absent in the most of 46, XX OT-DSD patients, and the mechanism underlying the testis development is not fully understood.

SOX genes are considered key players in the regulation of nervous system development and embryogenesis; they encode transcription factors that act as key regulators in a variety of developmental processes, including specification, gastrulation, cellular differentiation, and neural induction (19). SOX9 is critical to the human testis differentiation, while it is still poorly understood whether SOX3 expression affects sex differentiation. A study showed knockout of SOX3 did not cause any defects of sex determination; however, affected testis differentiation and oocyte development were observed in SOX3-null mice (20). Moreover, another study showed that SOX3 mutations were absent in the subjects diagnosed with 46 , XY gonadal dysgenesis and 46, XX sex reversal, indicating that SOX3 might not be involved in testis differentiation (21). Recent studies have shown that several human XX male sex reversal cases present rearrangements of the SOX3 locus, suggesting that a defect in the SOX3 gene might result in XX male sex reversal in mice and humans. Therefore, researchers believe that $S R Y$ may arise from SOX 3 and the two genes have interchangeable functions in sex determination $(16,22)$. 
The study conducted by Sutton et al. (16) showed three patients with XX male sex reversal exhibiting rearrangements encompassing or in proximity of SOX3. Patient A had two microduplications, one of which covered the entire SOX3 gene; patient $\mathrm{B}$ carried a microdeletion located upstream of SOX3 in Xq27.1; patient $\mathrm{C}$ had a large duplication that encompassed the SOX3 gene and at least 18 additional genes, which might be responsible for the clinical phenotype (Table 1). Additionally, another study by Moalem et al. (22) showed de novo SOX3 gene duplication in XX male sex reversal with genital abnormalities. The patient exhibited a partial sex reversal with abnormal genitalia and had three copy number variants, the first of which was a $494-\mathrm{kb}$ duplication in region Xq27.1, which encompassed the SOX3 gene. The phenotype might be associated with weak or slightly late ectopic expression of SOX3 in the early gonads. Subsequently, a study (18) identified the first 46, XX OT-DSD case who showed a SOX3 duplication, with absence of SRY, and presented hypospadias and bilateral cryptorchidism (Table $\mathbf{1}$ ).

In our study, we secondly identified a 46, XX OT-DSD case with SOX3 gene duplication, which was first found in Chinese individuals. The findings are in agreement with the previous studies, supporting the notion that duplication of $S O X 3$ is responsible for partial testicular differentiation in the fetal XX gonads. In this study, apart from the SOX3 gene, 11 OMIM genes were also involved in this duplicated region. Previous studies indicated that the MAGE genes and SPANX genes are specifically expressed in tumors and testis (23-25), which needs further investigation as to the potential relationship between these genes and sex determination.

In conclusion, our study firstly identified a patient carrying the Xq27.1q27.2 duplication involving the SOX3 gene in a 46, XX OT-DSD Chinese individual, which provides additional evidence that the duplication of SOX3 is pathological in the XX OT-DSD and further indicates that SOX3 may be the evolutionary antecedent of SRY. However, more work can be done on the expression of SOX9 or other genes that

\section{REFERENCES}

1. Houk CP, Hughes IA, Ahmed SF, Lee PA, Writing Committee for the International Intersex Consensus Conference Participants. Summary of consensus statement on intersex disorders and their management. International Intersex Consensus Conference. Pediatrics. (2006) 118:753-7. doi: 10.1542/peds.2006-0737

2. Lee PA, Houk CP, Ahmed SF, Hughes IA, International Consensus Conference on Intersex organized by the Lawson Wilkins Pediatric Endocrine Society and the European Society for Paediatric Endocrinology. Consensus statement on management of intersex disorders. International Consensus Conference on Intersex. Pediatrics. (2006) 118:e488-500. doi: 10.1542/peds.2006-0738

3. McElreavey K, Cortes LS. X-Y translocations and sex differentiation. Semin Reprod Med. (2001) 19:133-9. doi: 10.1055/s-2001-15393

4. Queipo G, Zenteno JC, Peña R, Nieto K, Radillo A, Dorantes LM, et al. Molecular analysis in true hermaphroditism: demonstration of low-level hidden mosaicism for Y-derived sequences in 46,XX cases. Hum Genet. (2002) 111:278-83. doi: 10.1007/s00439-002-0772-9 affect the gonadal differentiation pathway, such as WNT4 or RSPO1.

\section{DATA AVAILABILITY STATEMENT}

The raw data supporting the conclusions of this article will be made available by the authors, without undue reservation.

\section{ETHICS STATEMENT}

The studies involving human participants were reviewed and approved by Ethics Committee of Quanzhou women's and children's hospital. We confirmed that all subjects who participated in this study signed written informed consent for publishing their own and their children's genetic data and relevant information.

\section{AUTHOR CONTRIBUTIONS}

JZ and CC designed the study and wrote the article. JW, SZ, and YW performed the karyotype analysis and analyzed the data. YJ, JL, YL, and YX revised and polished the manuscript. All authors approved the final article.

\section{FUNDING}

This research was supported by the Fujian Provincial Health Commission Youth Science and Technology Project (2020QNB045) and Quanzhou City Science and Technology Project (2020C026R).

\section{ACKNOWLEDGMENTS}

We wish to express our appreciation to Fujian Provincial Health Commission and Quanzhou City Science and Technology Bureau for funding this work. We also express our appreciation to the patient and his family members who participated in this study.
5. Krob G, Braun A, Kuhnle U. True hermaphroditism: geographical distribution, clinical findings, chromosomes and gonadal histology. Eur J Pediatr. (1994) 153:2-10. doi: 10.1007/BF02000779

6. Délot EC, Vilain EJ. Nonsyndromic46,XX testicular disorders of sex development. In: Adam MP, Ardinger HH, Pagon RA, Wallace, SE, Bean, LJH, Stephens, K, et al. GeneReviews $($ ). Seattle, WA: University of Washington (2003).

7. Piprek RP. Genetic mechanisms underlying male sex determination in mammals. J Appl Genet. (2009) 50:347-60. doi: 10.1007/BF03195693

8. Vidal VP, Chaboissier MC, de Rooij DG, Schedl A. Sox9 induces testis development in XX transgenic mice. Nat Genet. (2001) 28:216-7. doi: 10.1038/90046

9. Croft B, Ohnesorg T, Hewitt J, Bowles J, Quinn A, Tan J, et al. Human sex reversal is caused by duplication or deletion of core enhancers upstream of SOX9. Nat Commun. (2018) 9:5319. doi: 10.1038/s41467-018-07784-9

10. Cox JJ, Willatt L, Homfray T, Woods CG. A SOX9 duplication and familial 46,XX developmental testicular disorder. N Engl J Med. (2011) 364:91-3. doi: 10.1056/NEJMc1010311 
11. Huang B, Wang S, Ning Y, Lamb AN, Bartley J. Autosomal XX sex reversal caused by duplication of SOX9. Am J Med Genet. (1999) 87:349-53. doi: 10. 1002/(SICI)1096-8628(19991203)87:4<349::AID-AJMG13>3.0.CO;2-N

12. Lee GM, Ko JM, Shin CH, Yang SW. A Korean boy with 46,XX testicular disorder of sex development caused by SOX9 duplication. Ann Pediatr Endocrinol Metab. (2014) 19:108-12. doi: 10.6065/apem.2014.19.2.108

13. Kamachi Y, Uchikawa M, Kondoh H. Pairing SOX off: with partners in the regulation of embryonic development. Trends Genet. (2000) 16:182-7. doi: 10.1016/S0168-9525(99)01955-1

14. Laumonnier F, Ronce N, Hamel BC, Thomas P, Lespinasse J, Raynaud M, et al. Transcription factor SOX3 is involved in X-linked mental retardation with growth hormone deficiency. Am J Hum Genet. (2002) 71:1450-5. doi: $10.1086 / 344661$

15. Woods KS, Cundall M, Turton J, Rizotti K, Mehta A, Palmer R, et al. Overand underdosage of SOX3 is associated with infundibular hypoplasia and hypopituitarism. Am J Hum Genet. (2005) 76:833-49. doi: 10.1086/430134

16. Sutton E, Hughes J, White S, Sekido R, Tan J, Arboleda V, et al. Identification of SOX3 as an XX male sex reversal gene in mice and humans. J Clin Invest. (2011) 121:328-41. doi: 10.1172/JCI42580

17. Tasic V, Mitrotti A, Riepe FG, Kulle AE, Laban N, Polenakovic M, et al. Duplication of the SOX3 gene in an Sry-negative 46,XX male with associated congenital anomalies of kidneys and the urinary tract: Case report and review of the literature. Balkan J Med Genet. (2019) 22:81-8. doi: 10.2478/bjmg-2019-0006

18. Grinspon RP, Nevado J, Mori Alvarez Mde L, Del Rey G, Castera R, Venara M, et al. 46,XXovotesticular DSD associated with a SOX3 gene duplication in a SRY-negative boy. Clin Endocrinol. (2016) 85:673-5. doi: 10.1111/cen.13126

19. Stagi S, Lapi E, Pantaleo M, Traficante G, Giglio S, Seminara S, et al. A SOX3 (Xq26.3-27.3) duplication in a boy with growth hormone deficiency, ocular dyspraxia, and intellectual disability: a long-term follow-up and literature review. Hormones. (2014) 13:552-60. doi: 10.14310/horm.2002.1523

20. Weiss J, Meeks JJ, Hurley L, Raverot G, Frassetto A, Jameson JL. Sox3 is required for gonadal function, but not sex determination, in males and females. Mol Cell Biol. (2003) 23:8084-91. doi: 10.1128/MCB.23.22.8084-8091.2003

21. Lim HN, Berkovitz GD, Hughes IA, Hawkins JR. Mutation analysis of subjects with 46, XX sex reversal and 46, XY gonadal dysgenesis does not support the involvement of SOX3 in testis determination. Hum Genet. (2000) 107:650-2. doi: $10.1007 / \mathrm{s} 004390000428$

22. Moalem S, Babul-Hirji R, Stavropolous DJ, Wherrett D, Bägli DJ, Thomas $\mathrm{P}$, et al. XX male sex reversal with genital abnormalities associated with a de novo SOX3 gene duplication. Am J Med Genet A. (2012) 158A:1759-64. doi: 10.1002/ajmg.a.35390

23. Lucas S, De Plaen E, Boon T. MAGE-B5, MAGE-B6, MAGEC2, and MAGE-C3: four new members of the MAGE family with tumor-specific expression. Int $J$ Cancer. (2000) 87:55-60. doi: 10.1002/1097-0215(20000701)87:1<55::AID-IJC8>3.0.CO;2-J

24. Lucas S, De Smet C, Arden KC, Viars CS, Lethé B, Lurquin C, et al. Identification of a new MAGE gene with tumor-specific expression by representational difference analysis. Cancer Res. (1998) 58:743-52.

25. Zendman AJ, Zschocke J, van Kraats AA, de Wit NJ, Kurpisz M, Weidle $\mathrm{UH}$, et al. The human SPANX multigene family: genomic organization, alignment and expression in male germ cells and tumor cell lines. Gene. (2003) 309:125-33. doi: 10.1016/S0378-1119(03)00497-9

Conflict of Interest: The authors declare that the research was conducted in the absence of any commercial or financial relationships that could be construed as a potential conflict of interest.

Copyright (c) 2021 Zhuang, Chen, Li, Jiang, Wang, Wang, Zeng, Lin and Xie. This is an open-access article distributed under the terms of the Creative Commons Attribution License (CC BY). The use, distribution or reproduction in other forums is permitted, provided the original author(s) and the copyright owner(s) are credited and that the original publication in this journal is cited, in accordance with accepted academic practice. No use, distribution or reproduction is permitted which does not comply with these terms. 